\title{
Metals toxicity and its bioaccumulation in purslane seedlings grown in controlled environment
}

\author{
Alia Naz ${ }^{1 *}$, Sardar Khan $^{2}$, Muhammad Qasim $^{1}$, Salma Khalid $^{1}$, Said Muhammad $^{3}$, \\ Muhammad Tariq ${ }^{3}$ \\ ${ }^{1}$ Department of Environmental Sciences, Shankar Campus, Abdul Wali Khan University, Mardan, Pakistan; \\ *Corresponding Author: environment soil@yahoo.com \\ ${ }^{2}$ Department of Environmental Sciences, University of Peshawar, Peshawar, Pakistan \\ ${ }^{3}$ Department of Earth Sciences, COMSATS Institute of Information Technology, Abbottabad, Pakistan
}

Received 14 March 2013; revised 16 April 2013; accepted 30 April 2013

Copyright (c) 2013 Alia Naz et al. This is an open access article distributed under the Creative Commons Attribution License, which permits unrestricted use, distribution, and reproduction in any medium, provided the original work is properly cited.

\begin{abstract}
We aimed to find the toxicological impacts of $\mathrm{Cd}$, $\mathrm{Pb}$ and $\mathrm{Zn}$ in single dozes and in combinations on Purslane (Portulaca oleracea) seedling. The Pursolane seedlings grown in pots in a green house were treated with different soil treatments spiked $(\mathrm{mg} / \mathrm{kg})$ with $\mathrm{Pb}(300,400$ and 500$)$, Cd $(0.5,1$ and 1.5), and $\mathrm{Zn}(250,500,700)$ alone and then in specified combinations/concentrations i.e., $\mathrm{Cd} / \mathrm{Pb}(0.5 / 300,1 / 400,1.5 / 500), \mathrm{Cd} / \mathrm{Zn}(0.5 / 250$, $1 / 500,1.5 / 700)$ and $\mathrm{Pb} / \mathrm{Zn}(300 / 250,400 / 500,500 /$ 700). The results indicated that increasing concentrations of the studied HMs in seedlings tissues significantly $(p<0.05)$ reduced the seedlings growth. Cd was more toxic to $P$. oleracea seedling, compared to $\mathrm{Pb}$ and $\mathrm{Zn}$. Roots of $P$. oleracea seedlings were more sensitive to the studied HMs in comparison with shoot. The uptake patterns showed antagonistic impacts on each other and were reflected in response to growth parameters. The combine toxicities of $\mathrm{Cd}, \mathrm{Pb}$ and $\mathrm{Zn}(\mathrm{Cd} / \mathrm{Pb}, \mathrm{Cd} / \mathrm{Zn}$ and $\mathrm{Pb} / \mathrm{Zn})$ were more than the toxicity due to single dose of each element but less than their additive sums.
\end{abstract}

Keywords: Heavy Metals; Seedlings Toxicity; Portulaca Oleracea; Heavy Metals Toxicity

\section{INTRODUCTION}

The vegetables irrigated with wastewater contain HMs, which are not only dangerous to plant life but also to animals and human beings [1,2]. For instance HMs accumulated in soil disturbs the soil ecosystem and plants development by reducing plant yield, affecting leaf \& root growth and inhibiting enzymatic activities [3-5].

With wastewater irrigation, normally HMs accumulates in the soil to high levels, which are toxic and can lead ecological consequences [6]. HMs enter to human body in different moods but the food chain contamination is one of the most important pathway, which contributes $90 \%$ compared to other routes like inhalation and dermal contact [7].

Many HMs like $\mathrm{Cd}$ and $\mathrm{Pb}$ are nonessential and toxic for plant growth [8], but plant takes them up rapidly when present in growing medium [9]. Cd is phytotoxic in nature, and it not only inhibits the growth of plants but also causes cell senescence [10]. Moreover Cd badly affects respiration and photosynthesis and decreases water and nutrient uptake by plants [11]. Cd reduces root growth by decreasing cell division [12], inhibits the activities of anti-oxidative enzymes of plants [13] and induces oxidative stress in cells [14].

Similarly, $\mathrm{Pb}$ causes retardation of plant growth and inhibition of seed germination [15], also it has significant negative impact on seedling bio mass, root length and shoot length [16]. Same as $\mathrm{Cd}, \mathrm{Pb}$ also adversely affects on photosynthesis, respiration and metabolism of plants [17]. Zn, which is one of the essential elements for many physiological processes, in higher concentrations affects mitotic activity [18], disturbs membrane integrity and permeability [19]. In high concentration Zn causes necrosis of shoot and inhibits root development [20,21]. $\mathrm{Cd}, \mathrm{Pb}$ and $\mathrm{Zn}$ jointly reduce the uptake of other essential elements like $\mathrm{Mn}, \mathrm{Fe}, \mathrm{K}, \mathrm{Mg}$ and $\mathrm{Ca}$ in plants [22]. This reduction causes low productivity and toxicity in plants in term of reduction in plant biomass.

According to Abedin \& Mehrage [23] both seedling and seed germination stage are important for the study of impacts of HMs. The study of the effects of individual 
HMs in control environment provide us useful information about HMs, but these information can not reflect the real exposure of plants to HMs in natural environment as the natural environment contains a mixture of different HMs. Thus effects of individual HMs on plants are different from the joint effects of mixture of HMs [24]. The combine effects of mixture of HMs depend on the components of mixture; either they have antagonistic or synergistic relationship [25]. So to evaluate the impacts of HMs on plants it is necessary to study them in combination doses as well. In the past the effects of the single HMs on plants were investigated by many researchers $[26,27]$ however there are few studies on joint effects of HMs on plants [28-30].

This paper investigates the toxicological effects of individual $\mathrm{Cd}, \mathrm{Pb}$ and $\mathrm{Zn}$ and their combination $(\mathrm{Cd} / \mathrm{Pb}$, $\mathrm{Cd} / \mathrm{Zn}$ and $\mathrm{Pb} / \mathrm{Zn}$ ) on seedling biomass (shoot and root fresh and dry weights), seedling lengths (shoot and root lengths), cell size, shoot diameter, number of leaves and mitotic index (MI) of P. Oleracae seedlings.

\section{METHODOLOGY}

\subsection{Soil Spiking with Heavy Metal}

Sub-soil from an uncontaminated site of Peshawar, Pakistan was collected with basic properties mentioned in Table 1. Soil was dried in open air and passed through a $5 \mathrm{~mm}$ sieve. The dried and sieved soil was spiked (mg/kg) with $\mathrm{Pb}$ (300, 400 and 500, Cd (0.5, 1 and 1.5), Zn (250, 500, 700), Cd/Pb (0.5/300, 1/400, 1.5/500), $\mathrm{Cd} / \mathrm{Zn}(0.5 / 250,1 / 500,1.5 / 700)$ and $\mathrm{Pb} / \mathrm{Zn}(300 / 250$, 400/500, 500/ 700). The spiked soil was then dried, thoroughly mixed and again sieved with a $5 \mathrm{~mm}$ sieve.

\subsection{Pot Filling}

Plastic pots were filled with 500 gm spiked soil and four replicates were prepared as required for scientific analysis.

Table 1. Basic properties of soil used for this study.

\begin{tabular}{lc}
\hline Parameter & Values \\
\hline $\mathrm{pH}$ & 7.7 \\
Organic matter $(\%)$ & 1.6 \\
EC $(\mathrm{dS} / \mathrm{m})$ & 6.71 \\
Soil particle size (\%) & \\
$<20 \mu \mathrm{m}$ & 7.6 \\
$20-62 \mu \mathrm{m}$ & 66 \\
$62-250 \mu \mathrm{m}$ & 25.7 \\
$250 \mu \mathrm{m}-1 \mathrm{~mm}$ & 0.577 \\
\hline
\end{tabular}

\subsection{Plant Material}

P. Oleracae seeds were kept in $30 \%(w / w) \mathrm{H}_{2} \mathrm{O}_{2}$ solution for $10 \mathrm{~min}$ for disinfection and then washed with deionized water. Seeds were germinated in Petri dishes for four days at $28^{\circ} \mathrm{C} \pm 1^{\circ} \mathrm{C}$ temperature. Four uniform seedlings were cultivated in each plastic pot. Pots were kept in a greenhouse with day temperature of $25^{\circ} \mathrm{C} \pm 4^{\circ} \mathrm{C}$ and night temperature of $19^{\circ} \mathrm{C} \pm 3^{\circ} \mathrm{C}$. Plants were under sun light of $12 \mathrm{~h}$ and relative humidity of $65 \% \pm 2 \%$. Deionized water was used to irrigate the seedlings. The pots were re-randomized for getting equal amount of sunlight and heat. The plants were harvested 2 weeks after cultivation.

\subsection{Recording Growth Parameters}

Fresh weight, length and diameter of the root and shoot were recorded and after drying in oven at $80^{\circ} \mathrm{C}$ for 3 days, dry weights were also recorded.

\subsection{Recording Growth Parameters}

Fresh weight, length and diameter of the root and shoot were recorded and after drying in oven at $80^{\circ} \mathrm{C}$ for 3 days, dry weights were also recorded.

\subsection{Mitotic Index}

Germinated seedlings were fixed in a mixture of ethanol-acetic acid (3:1) for $24 \mathrm{~h}$, hydrolyzed in $1 \mathrm{M} \mathrm{HCl}$ for $10 \mathrm{~min}$ and stained in $2 \%$ aceto-orcine. The root tips were cut off in a drop of $45 \%$ acetic acid, macerated and squashed following Sharma \& Sharma [31] methodology. The prepared slides were carefully observed under light microscope and MI was calculated with the following formula.

MI $(\%)=($ Number of dividing cells/Total number of cells) $\times 100$.

\subsection{Heavy Metals Extraction and Analysis}

The Grinded seedlings were weighted and about $0.5 \mathrm{~g}$ was put in acid washed and dried digestion tube. The powdered seedling with a mixture of $(15 \mathrm{ml})$ of $\mathrm{HNO}_{3}$, $\mathrm{HClO}_{4}$, and $\mathrm{H}_{2} \mathrm{SO}_{4}$ (5:1:10) were left overnight. On following day the digestion tubes were placed on a digestion block at a temperature of $80^{\circ} \mathrm{C}$ for $1 \mathrm{~h}$ and then raised to $120^{\circ} \mathrm{C}-130^{\circ} \mathrm{C}$ till clear solution obtained. The digested, transparent solutions were filtered into acid washed volumetric flasks and make the volume $50 \mathrm{ml}$ with double deionized water, with the help of atomic absorption spectrometer (Analyst 700 PerkElmer).

\subsection{Quality Control}

For verification the accuracy and precision of diges- 
tion procedure a reagent blank and standard reference soil and vegetable sample were included in our samples.

\subsection{Statistical Analysis}

The data were taking as the means of four replicates and statistically analyzed using SPSS. Analysis of variance (ANOVA) and Duncan Multiple Range test (DMRT) was used for confirmation variability and validity and statistical significance between the treatments respectively. Linear regression analysis was performed to establish the relationships between the HM concentrations in the plants tissues and the HM concentrations in the soil.

\section{RESULTS}

\subsection{Heavy Metals Impacts on Plant Biomass}

P. Oleracae seedling was significantly $(\mathrm{p}<0.05)$ affected with increasing concentrations of $\mathrm{Cd}, \mathrm{Pb}$ and $\mathrm{Zn}$ when applied alone or in cobination. Maximum high dose of Cd remarkably decreased the shoot and root fresh weight $(42.3 \%$ and $38.1 \%)$ as well as its dry weights (34.9\% and 39.2\%). Pb high doses has the similar im- pacts while the addition of $\mathrm{Zn}$ high dose, decreased shoot and root fresh weight with a bit mild ratio (37.5\%, 29.4\%) compared to other toxicants in the study. The combine application of $\mathrm{Cd} / \mathrm{Pb}$ in growing medium reduced shoot and root fresh and dry weights (up to 49.17\%) from control.

Shoot and root fresh and dry weights were also significantly reduced ranging from $36.6 \%$ to $43.0 \%$, respectively in comparison with the control due to highest dose of $\mathrm{Cd} / \mathrm{Zn}$. Similarly at the highest dose of $\mathrm{Pb} / \mathrm{Zn}$ shoot and root fresh and dry weights were reduced by 47.8\%, 40.3\%, 34.2\% and 39.2\%, (Table 2) respectively. It is notable that the dry weights of both shoot and root were more affected than their fresh weights of studied seedlings.

\subsection{Heavy Metals Impacts on Plant Height}

$\mathrm{Cd}, \mathrm{Pb}, \mathrm{Zn}, \mathrm{Cd} / \mathrm{Pb}, \mathrm{Cd} / \mathrm{Zn}$ and $\mathrm{Pb} / \mathrm{Zn}$ had a significant $(\mathrm{p}<0.05)$ toxicological impacts on shoot and root lengths of $P$. oleracea seedlings. The highest dose of $\mathrm{Cd}$ and $\mathrm{Pb}$ and $\mathrm{Zn}$ reduced shoot lengths by 24.4\%, 22.9\% and $21.4 \%$, respectively (Table 2 ). It means that $\mathrm{Pb}$ had the most adverse impact on plant height. Similarly shoot

Table 2. Percent reduction in growth parameters due to HM treatments control group.

\begin{tabular}{|c|c|c|c|c|c|c|c|c|c|}
\hline \multirow{2}{*}{ Treatments } & \multicolumn{4}{|c|}{ Seedlings biomass } & \multicolumn{3}{|c|}{ Length } & \multirow{2}{*}{$\begin{array}{l}\text { No of } \\
\text { leave }\end{array}$} & \multirow{2}{*}{ MI } \\
\hline & Shoot fresh weigh & Root fresh weight & Shoot dry weight & Root dry weight & Shoot length & Root length & Shoot diameter & & \\
\hline Cd 2 & 33.1 & 30.6 & 24.2 & 25.8 & 23.5 & 29.2 & 19.6 & 40.9 & 11.7 \\
\hline $\mathrm{Cd} 3$ & 42.3 & 38.1 & 34.9 & 39.2 & 24.4 & 29.2 & 24.9 & 45.5 & 13.5 \\
\hline $\mathrm{Pb} 1$ & 10.0 & 23.1 & 14.0 & 18.0 & 17.9 & 21.3 & 16.0 & 25.9 & 4.20 \\
\hline $\mathrm{Pb} 2$ & 15.0 & 25.6 & 16.3 & 23.5 & 19.8 & 25.8 & 17.4 & 27.5 & 6.60 \\
\hline $\mathrm{Pb} 3$ & 38.1 & 33.1 & 32.6 & 38.3 & 22.9 & 27.2 & 19.5 & 29.5 & 9.60 \\
\hline $\mathrm{Zn} 1$ & 9.00 & 20.3 & 12.1 & 16.7 & 10.2 & 19.6 & 13.6 & 22.3 & 4.40 \\
\hline Zn 3 & 37.5 & 29.4 & 24.7 & 37.3 & 21.4 & 25.0 & 17.5 & 28.6 & 9.30 \\
\hline $\mathrm{Cd} 1 / \mathrm{Pb} 1$ & 15.0 & 30.0 & 20.6 & 25.3 & 23.1 & 27.3 & 20.8 & 36.9 & 11.9 \\
\hline $\mathrm{Cd} 2 / \mathrm{Pb} 2$ & 35.0 & 33.3 & 27.3 & 27.8 & 27.6 & 37.9 & 23.3 & 45.5 & 12.5 \\
\hline $\mathrm{Cd} 3 / \mathrm{Pb} 3$ & 45.2 & 40.0 & 40.4 & 49.17 & 30.2 & 39.1 & 27.4 & 47.3 & 15.1 \\
\hline Cd1/Zn 1 & 15.4 & 26.9 & 35.5 & 40.5 & 23.5 & 26.1 & 19.3 & 36.4 & 9.50 \\
\hline Cd2/Zn 2 & 34.6 & 33.0 & 26.3 & 27.6 & 27.4 & 32.1 & 23.1 & 43.6 & 13.9 \\
\hline Cd3/Zn 3 & 43.6 & 40.0 & 36.6 & 40.0 & 27.3 & 32.4 & 26.6 & 47.9 & 15.1 \\
\hline $\mathrm{Zn} 1 / \mathrm{Pb} 1$ & 11.2 & 24.6 & 16.7 & 20.0 & 21.8 & 25.9 & 20.8 & 28.6 & 6.60 \\
\hline $\mathrm{Zn} 2 / \mathrm{Pb} 2$ & 17.2 & 27.0 & 18.9 & 27.3 & 31.2 & 27.3 & 20.0 & 28.2 & 7.40 \\
\hline
\end{tabular}


and root lengths were reduced by $30.2 \%$ and $39.1 \%$ due to the highest dose of $\mathrm{Cd} / \mathrm{Pb}$.

Similarly at the highest dose of $\mathrm{Cd} / \mathrm{Zn}$ root lengths were reduced by $32.4 \%$. The addition of highest dose of $\mathrm{Pb} / \mathrm{Zn}$ reduced root lengths by $30.4 \%$ (Table 2).

\subsection{Heavy Metals Impacts on Plant Secondary Growth}

Apart from vertical growth, heavy metals also adversely affected the longitudinal growth as the diameter of $P$. oleracea plants parts showed in response to different concentrations of $\mathrm{Cd}, \mathrm{Pb}, \mathrm{Zn}, \mathrm{Cd} / \mathrm{Pb}, \mathrm{Cd} / \mathrm{Zn}$ and $\mathrm{Pb} / \mathrm{Zn}$. Shoot diameters were reduced by $24.9 \%, 19.5 \%, 17.5 \%$, $27.4 \%, 26.6 \%$ and $23.4 \%$ due to the highest doses of $\mathrm{Cd}$, $\mathrm{Pb}, \mathrm{Zn}, \mathrm{Cd} / \mathrm{Pb}, \mathrm{Cd} / \mathrm{Zn}$ and $\mathrm{Pb} / \mathrm{Zn}$, respectively. In all three treatments of combine toxicity $(\mathrm{Cd} / \mathrm{Pb}, \mathrm{Cd} / \mathrm{Zn}, \mathrm{Pb} /$ $\mathrm{Zn}$ ) the shoot diameters were more affected as compare to their single dose.

\subsection{Heavy Metals Impacts on Plant Number of Leaves and Mitotic Index}

The increasing concentrations of HMs resulted in a significant decrease in the cell size, number of leaves and root mitotic index of $P$. Oleracae seedlings as our result showed (Table 2). At the highest dose of $\mathrm{Cd}, \mathrm{Pb}$ and $\mathrm{Zn}$ the number of leaves and MI were drastically reduced. The reduction in number of leaves and MI were $47.3 \%$ and $15.1 \%$ due to the highest dose of $\mathrm{Cd} / \mathrm{Pb}$. Similarly at highest dose of $\mathrm{Pb} / \mathrm{Zn}$, number of leaves and MI were reduced by $31.8 \%$ and $10.5 \%$, respectively as compared to control.

\subsection{Heavy Metal Uptake by Plants}

The relationships between the $\mathrm{Cd}$ concentrations in soil and in seedling tissue are given in Figure 1. All three relationships, i.e. between the single Cd concentration in soil and seedlings (Figure 1(a)), between $\mathrm{Cd} / \mathrm{Pb}$ in soil and in seedlings (Figure 1(b)) and between $\mathrm{Cd} / \mathrm{Zn}$ in soil and in seedlings (Figure 1(c)), show that with increasing concentrations of $\mathrm{Cd}$ in soil whether in single form or in mixture, accumulate in large amount in seedling tissues. Seedlings accumulated Cd, 42.3, 16.1 and 10.1 times of its concentration in the soil spiked with single $\mathrm{Cd}, \mathrm{Cd} / \mathrm{Pb}$ and $\mathrm{Cd} / \mathrm{Zn}$ treatments, respectively (Figure 2). Similarly, $\mathrm{Pb}$ concentrations in seedlings showed increasing trend. The regression analysis showed positive relationships between the concentrations of $\mathrm{Pb}$ in soil and in seedlings in all the three treatments i.e. single $\mathrm{Pb}, \mathrm{Pb} / \mathrm{Cd}$ and $\mathrm{Pb} / \mathrm{Zn}$. (Figures 3(a)-(c)). Figure 4 presents that seedlings accumulated $35 \%, 31 \%$ and $10.1 \%$ of $\mathrm{Pb}$ from single $\mathrm{Pb}$, $\mathrm{Pb} / \mathrm{Cd}$ and $\mathrm{Pb} / \mathrm{Zn}$ treatments, respectively. The regression analysis showed strong positive relationship between the

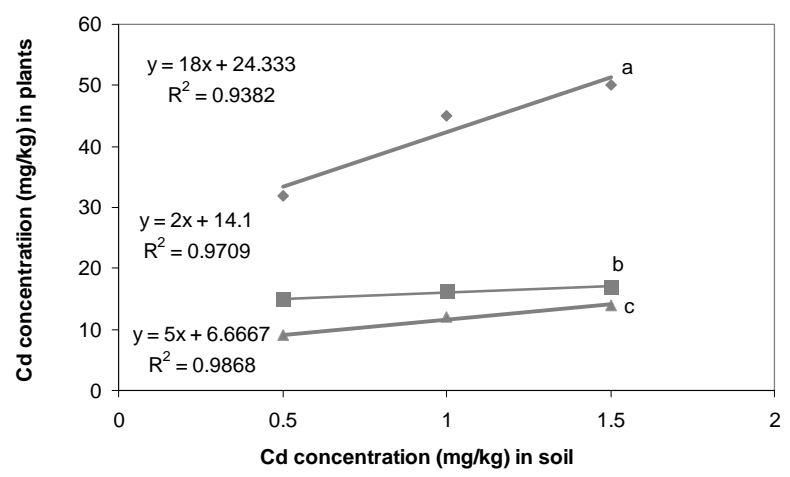

Figure 1. Cd concentrations in soil and seedlings tissues on dry weight basis; (a) Cd concentration in soil and seedlings in single Cd treatments; (b) Cd concentration in soil and seedlings in $\mathrm{Cd} / \mathrm{Pb}$ treatments; (c) $\mathrm{Cd}$ concentration in soil and seedlings in $\mathrm{Cd} / \mathrm{Zn}$ treatments.

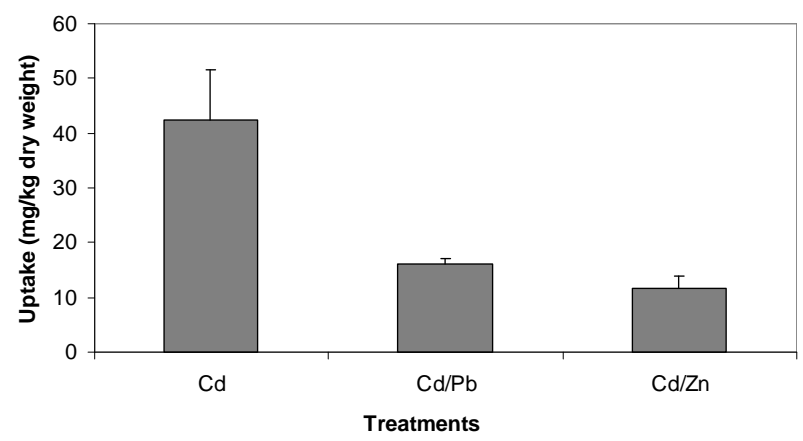

Figure 2. Comparison of Cd uptake from different treatments.

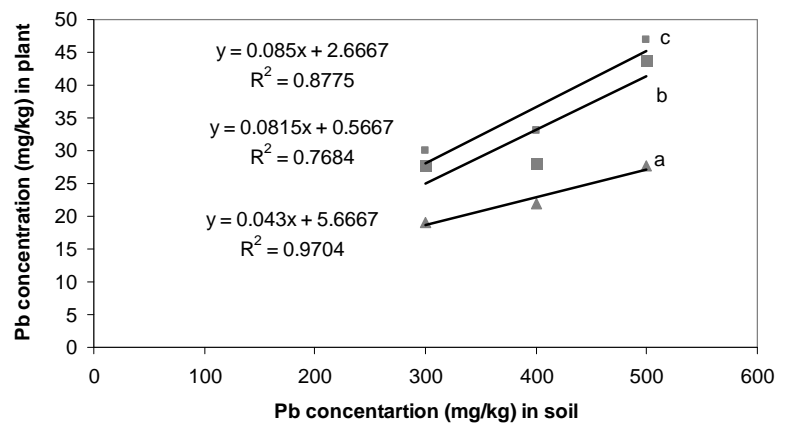

Figure 3. $\mathrm{Pb}$ concentrations in soil and seedlings tissues on dry weight basis; (a) $\mathrm{Pb}$ concentration in soil and seedlings in $\mathrm{Pb} /$ $\mathrm{Zn}$ treatments; (b) $\mathrm{Pb}$ concentration in soil and seedlings in $\mathrm{Cd} /$ $\mathrm{Pb}$ treatments; (c) $\mathrm{Pb}$ concentration in soil and seedlings in Single $\mathrm{Pb}$ treatments.

$\mathrm{Zn}$ concentration in soil and seedlings in single $\mathrm{Zn}, \mathrm{Zn} /$ $\mathrm{Cd}$ and $\mathrm{Zn} / \mathrm{Pb}$ treatments (Figures 5(a)-(c)). P. Oleracae seedlings accumulated $27.5 \%, 26.9 \%$ and $26.8 \%$, of $\mathrm{Zn}$ concentration in the soil in single $\mathrm{Zn}, \mathrm{Zn} / \mathrm{Cd}$ and $\mathrm{Zn} / \mathrm{Pb}$ treatments, respectively (Figure 6).

\section{DISCUSSION}

Plants have the ability to accumulate HMs in their 


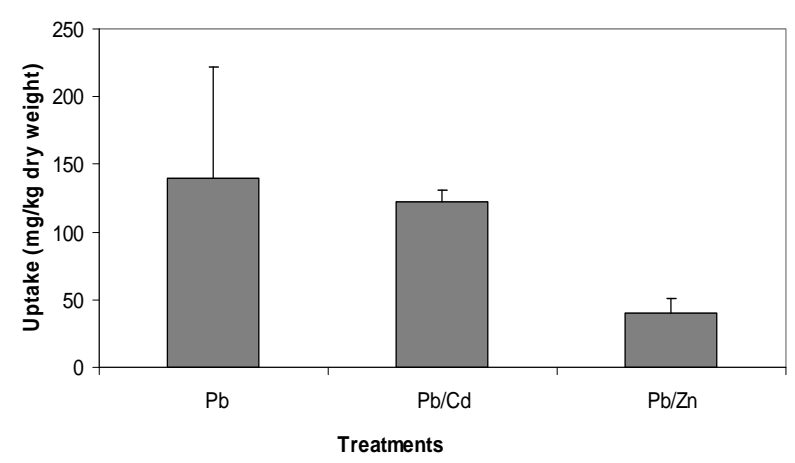

Figure 4. Comparison of $\mathrm{Pb}$ uptake from different treatments.

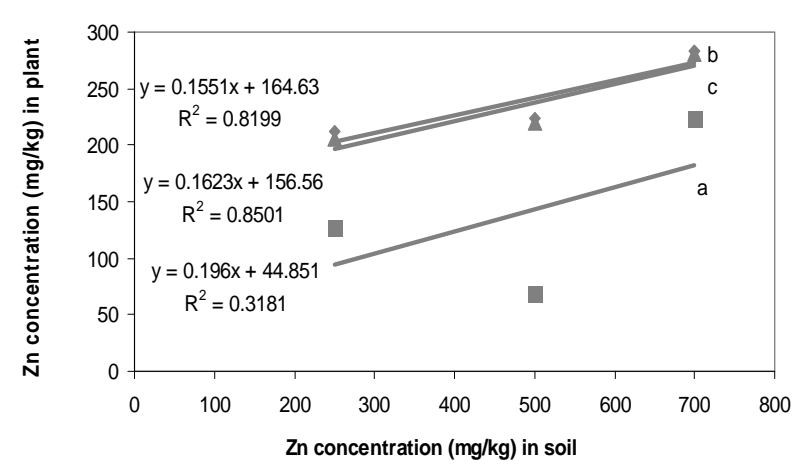

Figure 5. Zn concentrations in soil and seedlings tissues on dry weight basis; (a) Zn concentration in soil and seedlings in $\mathrm{Zn} / \mathrm{Cd}$ treatments; (b) $\mathrm{Zn}$ concentration in soil and seedlings in $\mathrm{Zn} / \mathrm{Pb}$ treatments; (c) Zn concentration in soil and seedlings in single $\mathrm{Zn}$ treatments.

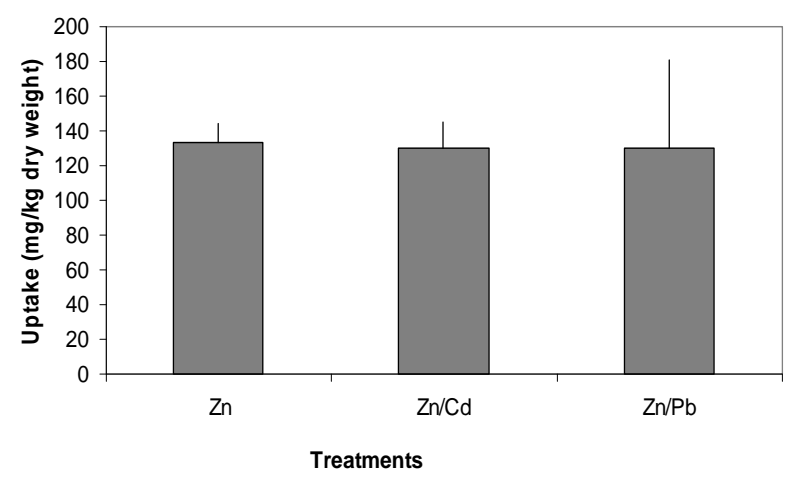

Figure 6. Comparison of $\mathrm{Zn}$ uptake from different treatments; Note: The error bars indicate the standard deviation.

body tissues when grow on HMs contaminated soil [2,4]. HMs are plants toxicant and affect plants badly. Zeng et al. [5] reported that HMs can reduce plant yield, affect leaf and root growth and inhibit enzymatic activities.

$\mathrm{Cd}$ inhibited plant growth and the toxicity increased with increasing concentration in soil. In the present study, increasing concentrations of Cd significantly reduced shoot and root fresh and dry weights. The results of pre- sent study are in line with the results of previous studies, for example Shute \& Macfie [32], Auda et al. [33], Xiaoli \& Shu-zhen [34] observed a reduction in biomass and lengths of soybean, carrot and wheat due to high concentration of Cd. On the other hand Fei-bo et al. [35] have not observed any reduction in plant growth however. Similarly other growth parameters like number of leaves, shoot diameter and MI were adversely affected with increasing concentrations of $\mathrm{Cd}$ which were also reported by Jun-yu et al. [36] in rice plant with increasing concentrations of $\mathrm{Cd}$. The increasing concentration of $\mathrm{Cd}$ is responsible for change the rate of photosynthesis. This reduces the synthesis of carbohydrates, protein and finally decreases the growth of plants [33].

Increasing concentrations of $\mathrm{Pb}$ significantly $(\mathrm{p}<0.05)$ reduced biomass, length, number of leaves, diameter and mitotic index of $P$. Oleracae seedlings. The results of the present study are consistent with the results of previous studies. For example in a study on different concentration of $\mathrm{Pb}$ in growing medium resulted a retarded growth of shoot and root in C. sativus [30]. Farooqi et al. [28] found a decrease in seedlings dry weight of A. lebbeck with the increasing concentrations of $\mathrm{Pb}$. The toxicity of $\mathrm{Pb}$ in P. Oleracae seedling in the form of reduction in shoots and root fresh and dry weights was less than the $\mathrm{Cd}$. It may be due to high uptake of Cd compared to $\mathrm{Pb}$.

$\mathrm{Zn}$ is an essential element for plants, but its excess can significantly damage plant growth [37]. The results of present study also revealed that increasing $\mathrm{Zn}$ concentrations are responsible for retarded growth in seedlings. Shoot and root fresh and dry weights were reduced with increasing Zn concentrations. Zn reduced plant biomass due to deficiency of macronutrients uptake as reported by Marschner [38], Mahmood et al. [20] and Rout \& Das [18].

The toxicities of HMs depend on their mobility from soil to root and then root to shoot [30]. The presence of $\mathrm{Pb}$ in growing medium reduced the uptake of $\mathrm{Cd}$ by plants and vice versa. The uptake pattern of both $\mathrm{Cd}$ and $\mathrm{Pb}$ was reflected in the growth parameters of $P$. Oleracae the results are agreed with the studies of $[8,39]$. The adverse impacts of $\mathrm{Cd} / \mathrm{Pb}$ were more severe than the negative impacts on growth due to $\mathrm{Cd}$ and $\mathrm{Pb}$ in single form but less than the additive of the toxicity due to $\mathrm{Cd}$ and $\mathrm{Pb}$. $\mathrm{Zn}$ and Cd are usually found together in ores because of similar physical and chemical properties. Our results are in line with the findings Koleli et al. [40] and Sharma et al. [41] who reported that due to the presence of $\mathrm{Cd}$ in growing medium, reduce the uptake of $\mathrm{Zn}$ and vice versa. The uptake pattern of $\mathrm{Cd}$ and $\mathrm{Zn}$ is reflected in the growth parameters of $P$. Oleracae seedlings. The toxicities due to $\mathrm{Cd}$ and $\mathrm{Zn}$ in all its three treatments were in order of $\mathrm{Cd} / \mathrm{Zn}>\mathrm{Cd}>\mathrm{Zn}$, but toxicity due to $\mathrm{Cd} / \mathrm{Zn}$ was less than the additive sum of toxicities due to $\mathrm{Cd}$ and $\mathrm{Pb}$. 
Weihong et al. [42] for V. zizanioides and Xu et al. [43] for ryegrass produced the same results.

\section{CONCLUSION}

Result concluded that increasing $\mathrm{Cd}, \mathrm{Pb}$ and $\mathrm{Zn}$ concentrations (single and mixture forms) produced significant ( $\mathrm{p}<0.05$ ) toxicity on P. oleracea seedlings. Result revealed that shoot and root lengths, shoot and root biomass, shoot diameter, number of leaves, MI and cell size of $P$. oleracea were significantly affected. The co-existence of $\mathrm{Zn}$ and $\mathrm{Pb}$ like other HMs also result the change in the uptake of them. $\mathrm{Zn}$ and $\mathrm{Pb}$ interact each other when present together. The uptake pattern of $\mathrm{Zn}$ and $\mathrm{Pb}$ in $\mathrm{Zn} / \mathrm{Pb}$ showed that both $\mathrm{Zn}$ and $\mathrm{Pb}$ affected the uptake of each other in antagonistic way. The uptake pattern was reflected in growth parameters. In case of P. Oleracae seedlings the toxicities due to $\mathrm{Zn}$ and $\mathrm{Pb}$ in all its three treatments were in order of $\mathrm{Zn} / \mathrm{Pb}>\mathrm{Zn}>\mathrm{Pb}$.

\section{ACKNOWLEDGEMENTS}

This study was financially supported by University of Peshawar and Higher Education Commission Islamabad, Pakistan.

\section{REFERENCES}

[1] Murtaza, G., Ghafoor, A., Qadir. M., Rashid, M.K. (2003) Accumulation and Bioavailability of $\mathrm{Cd}$, Co and $\mathrm{Mn}$ in Soils and Vegetables Irrigated with City Effluent. Pakistan Journal of Agriculture Sciences, 40, 18-24.

[2] Khan, S., Aijun, L., Zhang, S., Hu, Q. and Zhu, Y.G. (2008) Accumulation of polycyclic aromatic hydrocarbons and heavy metals in lettuce grown in the soils contaminated with long-term wastewater irrigation. Journal of Hazardous Material, 152, 506-515. doi:10.1016/j.jhazmat.2007.07.014

[3] Khan, S., Cao, Q., Zheng, Y.M., Huang, Y.Z. and Zhu, Y.G. (2008) Health risks of heavy metals in contaminated soils and food crops irrigated with wastewater in Beijing, China. Environmental Pollution, 152, 686-692. doi:10.1016/j.envpol.2007.06.056

[4] Muhammad, S., Shah, M.T. and Khan S. (2011) Heavy metal concentrations in soil and wild plants growing around $\mathrm{Pb}-\mathrm{Zn}$ sulfide terrain in the Kohistan region, northern Pakistan. Microchemical Journal, 99, 67-75. doi:10.1016/j.microc.2011.03.012

[5] Zeng, X., Li, L. and Mei, X. (2008) Heavy metals contents in Chinese vegetable plantation land soil and related sources analysis. Journal of Agriculture Science in China, 7, 1115-1126. doi:10.1016/S1671-2927(08)60154-6

[6] Wang, X., Sato, T., Xing, B. and Tao, S. (2005) Health risks of heavy metals to the general public in Tianjin, China Via consumption of vegetables and fish. Science of the Total Environment, 350, 28-37. doi:10.1016/j.scitotenv.2004.09.044

[7] Loutfy, N., Fuerhacker, M., Tundo, P., Raccanelli, S., El
Dien, A.G. and Ahmed, M.T. (2006) Dietary intake of dioxins and dioxin-like PCBs, due to the consumption of dairy products, fish/seafood and meat from Ismailia city, Egypt. Science of the Total Environment, 370, 1-8. doi:10.1016/j.scitotenv.2006.05.012

[8] Zhiqiang, X., Qixing, Z. and Weitao, L. (2009) Joint effects of cadmium and lead on seedlings of four Chinese cabbage cultivars in northeastern China. Journal of Environmental Sciences, 21, 1598-1606.

doi:10.1016/S1001-0742(08)62461-4

[9] Fusconi, A., Repetto, O., Bona, E., Massa, N., Gallo, C., Dumas-Gaudot, E. and Berta, G. (2006) Effects of cadmium on meristem activity and nucleus ploidy in roots of Pisum sativum L. cv. Frisson seedlings. Environmental and Experimental Botany, 58, 253-260. doi:10.1016/j.envexpbot.2005.09.008

[10] Toppi, S.L. and Gabrielli, R. (1999) Response to cadmium in higher plants. Environmental and Experimental Botany, 41, 105-130. doi:10.1016/S0098-8472(98)00058-6

[11] Kuo, M.C. and Kao, C.H. (2004) Antioxidant enzyme activities are upregulated in response to cadmium in sensitive, but not in tolerant rice (Oryza sativa L.) seedlings. Botanical Bulletin of Academia Sinica, 45, 291-299.

[12] Liu, W.J., Zhu, Y.G., Smith, F.A. and Smith, S.E. (2004) Do iron plaque and genotypes affect arsenate uptake and translocation by rice. Journal of Experimental Botany, 55, 1707-1713. doi:10.1093/jxb/erh205

[13] Correa, A.D.R., Rorig, L.R., Verdinelli, M.A., Cotelle, S., Ferard, J.F. and Radetski, C.M. (2006) Cadmium phytotoxicity: Quantitative sensitivity relationships between classical endpoints and anti oxidative enzyme biomarkers. Science of the Total Environment, 357, 120-127. doi:10.1016/j.scitotenv.2005.05.002

[14] Sandalio, L.M., Dalurzo, H.C., Gomez, M., Romero-Puertas, M.C. and del Rio, L.A. (2001) Cadmium-induced changes in the growth and oxidative metabolism of pea plants. Journal of Experimental Botany, 52, 2115-2126.

[15] Iqbal, M.Z. and Shazia, Y. (2004) Reduction of germination and seedling growth of Leucaena leucocephala caused by lead and cadmium individually and combination. Ekologia (Braslava), 23, 162-168.

[16] Joseph, L.U., Andrea, L.C. and Mal, T.K. (2002) Effects of lead contamination on the growth of Lythrum salicaria. Environmental Pollution, 120, 319-323. doi:10.1016/S0269-7491(02)00144-6

[17] Paolacci, A.R., Badiani, M., Dannibale, A., Fusari, A. and Matteucci, G. (1997) Antioxidants and photosynthesis in the leaves of Triticum durum Desf seedlings acclimated to non-stressing high temperature. Journal of Plant Physiology, 150, 381-387. doi:10.1016/S0176-1617(97)80086-7

[18] Rout, G.R. and Das, P. (2003) Effect of metal toxicity on plant growth and metabolism: I. Zinc. Agronomy, 23, 311. doi:10.1051/agro:2002073

[19] Stoyanova, Z. and Doncheva, S. (2002) The effect of zinc supply and succinate treatment on plant growth andmineral uptake in pea plant. Braz. Journal of Plant Physiology, 14, 111-116. doi:10.1590/S1677-04202002000200005 
[20] Mahmood, S., Hussain, A., Saeed, Z. and Athar, M. (2005) Germination and seedling growth of corn (Zea mays l.) under varying levels of copper and zinc. International Journal of Environmental Science and Technology, 2, 269274.

[21] Lingua, G., Franchin, C., Todeschini, V., Castiglione, S., Biondi, S., Burlando, B., Parravicini, V., Torrigiani, P. and Berta, G. (2008) Arbuscular mycorrhizal fungi differetially affect the response to high zinc concentrations of two registered poplar clones. Journal of EnvironmentalSciences, 153, 137-147.

[22] Wu, F.B. and Zhang, G.P. (2002) Genotypic differencesin effect of Cd on growth and mineral concentrations inbarley seedling. Bulletin of Environmental Contamination and Toxicology, 69, 219-227. doi:10.1007/s00128-002-0050-5

[23] Abedin, M.J. and Meharg, A.A. (2002) Relative toxicity of arsenite and arsenate on germination and early seedling growth of rice (Oryza sativa L.). Plant Soil, 243, 57-66. doi:10.1023/A:1019918100451

[24] Zhou, Q.X., Zhang, Q.R. and Liang, J.D. (2006) Toxic effects of acetochlor and methamidops on earthworm Eisenia fetida in Phaeozem, Northeast China. Journal of Environmental Sciences, 18, 741-745.

[25] Jensen, J. and Sverdrup, L.E. (2002) Joint toxicity of linear alkylbenzene sulfonates and pyrene on Folsomia fimetaria. Ecotoxicology and Environmental Safety, 52, 7581. doi:10.1006/eesa.2002.2149

[26] He, J.Y., Zhu, C., Ren, Y.F., Yan, Y.P., Cheng, C., Jiang, D.A. and Sun, Z.X. (2008) Uptake, subcellular distribution, and chemical form of cadmium in wild-type and mutant rice. Pedosphere, 18, 371-377. doi:10.1016/S1002-0160(08)60027-2

[27] Yang, Y., Zhang, F., Li, H. and Jiang, R. (2009) Accumultion of cadmium in the edible parts of six vegetable species grown in Cd-contaminated soils. Journal of Environmental Management, 90, 1117-1122. doi:10.1016/j.jenvman.2008.05.004

[28] Farooqi, Z.R., Iqbal, M.Z., Kabir, M. and Shafiq, M. (2009) Toxic effects of lead and cadmium on germination and seedling growth of albizia lebbeck Benth. Pakistan Journal of Botany, 41, 27-33.

[29] Huang, S.S., Liao, Q.L., Hua, M., Wu, X.M., Bi, K.S., Yan, C.Y., Chen, B. and Zhang, X.Y. (2007) Survey of heavy metal pollution and assessment of agricultural soil in Yangzhong district, Jiangsu Province, China. Chemosphere, 67, 2148-2155.

doi:10.1016/j.chemosphere.2006.12.043

[30] An, Y., Kim, Y., Kwon, T. and Jeong, S. (2004) Combined effect of copper, cadmium, and lead upon Cucumis sativus growth and bioaccumulation. Science of the Total Environment, 326, 85-93. doi:10.1016/j.scitotenv.2004.01.002

[31] Sharma, A.K. and Sharma, A. (1980) Chromosome Techniques, Theory and Practice. Butterworths, London, 711.
[32] Shute, T. and Macfie, S.M. (2006) Cadmium and zinc accumulation in soybean: A threat to food safety? Science of the Total Environment, 371, 63-73. doi:10.1016/j.scitotenv.2006.07.034

[33] Auda, A.M. and Ali, E.S. (2010) Cadmium and zinctoxicity effects on growth and Mineral nutrients of carrot (daucus carota). Pakistan Journal of Botany, 42, 341351.

[34] Xiao-Li, L. and Shu-Zhen, Z. (2007) Intra specific differences in effects of co-contamination of cadmium and arsenate on early seedling growth and metal uptake by wheat. Journal of Environmental Sciences, 191, 221-1227.

[35] Fei-Bo, W., Jing, D., Guo-Xia, J., Shan-Jiu, Z. and GuoPing, Z. (2006) Genotypic difference in the responses of seedling growth and Cd toxicity in rice (Oryza sativa L.). Journal of Agriculture Science in China, 5, 68-76. doi:10.1016/S1671-2927(06)60021-7

[36] Jun-Yu, H., Yan-Fang, R., Cheng, Z. and De-An, J. (2008) Effects of cadmium stress on seed germination, seedling growth and seed amylase activities in rice (Oryza sativa). Rice Science, 15, 319-325. doi:10.1016/S1672-6308(09)60010-X

[37] Wang, C., Zhang, S.H., Wang, P.F., Hou, J., Zhang, W.J., Li, W. and Lin, Z.P. (2009) The effect of excess Zn on mineral nutrition and antioxidative response in rapeseed seedlings. Chemosphere, 75, 1468-1476. doi:10.1016/j.chemosphere.2009.02.033

[38] Marschner, H. (1995) Mineral nutrition of higher plants. 2nd Edition, Academic Press, San Diego.

[39] Kalavrouziotis, I.K., Koukoulakis, P.H., Manours, G. and Papadopoulos, A.H. (2009) Interactions between cadmium, lead, cobalt and nickel in broccoli, irrigated with treated municipal wastewater. European Water, 25-26, 13-23.

[40] Koleli, N., Eker, S. and Cakmak, I. (2004) Effect of fertilizer on cadmium toxicity in durum and bread wheat grown in zinc-deficient soil. Environmental Pollution, 131, 453-459. doi:10.1016/j.envpol.2004.02.012

[41] Sharma, S.S., Schat, H., Vooijs, R., Van Heerwaarden, L.M. (1999) Combination toxicology of copper, zinc, and cadmium in binary mixtures: Concentration-dependent antagonistic, non additive and synergistic effects on root growth in Silene vulgaris. Environmental Toxicology and Chemistry, 18, 348-355.

[42] Weihong, X., Wenyi, L., Jianping, H., Singh, B. and Zhiting, X. (2009) Effects of insoluble Zn, Cd, and EDTA on the growth, activities of antioxidant enzymes and uptake of $\mathrm{Zn}$ and $\mathrm{Cd}$ in Vetiveria zizanioides. Journal of Environmental Sciences, 21, 186-192. doi:10.1016/S1001-0742(08)62249-4

[43] Xu, J., Yang, L., Wang, Z., Dong, G., Huang, J. and Wang, Y. (2006) Toxicity of copper on rice growth and accumulation of copper in rice grain in copper contaminated soil. Chemosphere, 62, 602-607. doi:10.1016/j.chemosphere.2005.05.050 